\title{
Going Digital to Address the School Psychologist Shortage
}

\author{
Daniel F. McCleary ${ }^{1}$ (D) $\cdot$ Frankie J. Clark $^{1} \cdot$ Jillian Dawes $^{1}$ (D) $\cdot$ Jaime M. Flowers ${ }^{1} \cdot$ Nina Ellis-Hervey ${ }^{1}$ \\ Accepted: 11 October 2020 / Published online: 2 November 2020 \\ (C) California Association of School Psychologists 2020
}

\begin{abstract}
Given the shortage of school psychologists, especially in rural areas, school psychology programs are beginning to emerge that provide students with the opportunity to attend classes through distance education (DE) methods (i.e., virtually). Despite many school psychology students and faculty holding negative perceptions of DE methods, the use of DE is expanding within the field of school psychology. This article provides an overview of existing DE programs and existing DE research, specific to school psychology, followed by a brief history of a DE option at Stephen F. Austin State University that began in Fall 2018. Solutions to common issues encountered with DE are also presented.
\end{abstract}

Keywords Distance education · Online instruction $\cdot$ School psychology shortage

The field of school psychology continues to experience a shortage of practitioners and trainers (Brock 2015; Castillo et al. 2014; Fagan 2004; Reeves 2016; Savage 2016). Dixon (2017) began a series of articles in the Communique asking other school psychology practitioners to discuss the role online education could play in addressing these shortages. Institutions such as Eastern Washington University (EWU), the University of Calgary, Wayne State University (WSU), Fort Hays State University, and the University of HoustonVictoria (Dixon et al. 2020; Drefs et al. 2015) already provide instruction to school psychology candidates through a variety of predominately distance education (DE) methods (e.g., online, hybrid/blended). The purpose of this article is to provide a brief history of DE programs, a summary of published DE research findings within the field of school psychology, information about a DE option provided by Stephen F. Austin State University (SFA), and recommendations for common issues associated with DE. Although this paper was originally written for programs contemplating incorporating DE into their program, searching for ways to address the school psychology shortage, or address low enrollment numbers the information is also useful for programs forced into providing DE options due to COVID-19.

Daniel F. McCleary

mcclearydf@sfasu.edu

1 Department of Human Services and Educational Leadership, Stephen F. Austin State University, 2100 N. Raguet St., Nacogdoches, TX 75962, USA

\section{Terminology}

$\mathrm{DE}$ and its different modalities (online, hybrid/blended) come with a slew of terms that may be unfamiliar or, at times, difficult to discern differences between. For an orientation to concepts and common terms related to DE, readers are encouraged to familiarize themselves with the concise work of Fischer et al. (2018), Moy et al. (2017), and Moy et al. (2018). In this paper, the term "face-to-face in-person" is used to refer to instruction physically occurring in the same room. The term "face-to-face virtually" refers to instruction wherein the instructor and some students physically meet in the classroom while other students attend the same classroom through virtual means (e.g., Zoom).

\section{A Brief History of DE Programs}

The first known school psychology program to offer DE was EWU, which began offering a certificate in 2000 before transitioning to an online Ed.S. program in 2015 (Ruby et al. 2017). Although an online program, EWU requires students to attend functions on campus to interact with faculty and other students (for a full description, see Waldron-Soler et al. 2019). In 2007, Canada's University of Calgary began an M.Ed. online school psychology program that also required students to be on campus for specific components of the program (for a full description, see Drefs et al. 2015). Fort Hays State University started a school psychology program in 2012 that only requires students to physically attend a five-day workshop (Dixon et al. 2020; Fort Hays State University n.d.). 
Since at least 2013, the University of Houston-Victoria has provided individuals an opportunity to earn a Specialist in School Psychology (SSP) degree by completing approximately $62 \%$ of the coursework in an online format and the other courses either face-to-face in-person or through interactive television (Dixon et al. 2020; Hendricker and Viola 2019). Beginning in 2018, WSU began offering a M.A. in School and Community Psychology online via synchronous classes that include on-campus students. Like other DE programs, WSU requires students to attend campus about one evening per semester (Dixon et al. 2020; Wayne State University n.d.).

\section{School Psychology DE Research}

Hendricker et al. (2017) surveyed school psychology program directors about DE perspectives. They reported $32-35 \%$ of school psychology programs provide instruction through some form of DE (i.e., online, hybrid/blended) despite it not being advertised in program handbooks or on websites. Of those programs, $45 \%$ provided DE in theory courses and $57 \%$ reported DE occurred in courses contained within the program but taught by non-program faculty. Furthermore, the overwhelming majority of programs containing some form of DE reported that neither the quality of the courses nor the program outcomes (i.e., Praxis scores, graduation rates, employment rates) decreased after switching to DE content delivery methods.

Viola et al. (2019) surveyed school psychology graduate students regarding their perceptions of the use of DE within school psychology graduate programs. In general, students expressed more favorable opinions on hybrid/blended courses than online courses. Only $40 \%$ of the participants perceived predominately online courses to be as beneficial as traditional face-to-face classes, whereas $75 \%$ believed hybrid/blended courses to be as beneficial as traditional classes. Participants who had taken online and hybrid/blended courses reported disadvantages to include lack of interaction with others, fewer mastered skills, and reduced quality of instruction. Nonetheless, participants who had taken online and hybrid/ blended courses in school psychology reported appreciation for the flexibility and convenience remote instruction allows, which provided them the opportunity to reach their educational goals.

More recently, Fischer et al. (2020) surveyed school psychology program faculty and found approximately $79 \%$ of school psychology programs include some form of DE instruction. This is a notable increase from the $32-35 \% \mathrm{DE}$ instruction reported by Hendricker et al. in 2017. Similar to the results found by Hendricker et al. (2017), Fischer et al. (2020) reported DE courses were more likely to be theorybased than skill-based (e.g., assessment) and faculty were more favorable of hybrid/blended courses than online courses.
It is also worth noting that approximately $34 \%$ of school psychology faculty reported having plans for additional online course instruction within the next four years.

Despite expressed concerns from program directors, faculty, and students, published data from the University of Calgary, University of Houston-Victoria, and EWU indicate students and alumni of DE programs are adequately trained and prepared for the workforce (Drefs et al. 2015; Hendricker and Viola 2019; Ruby et al. 2017; Schroeder 2019; WaldronSoler et al. 2019).

\section{Stephen F. Austin State University}

The School Psychology Program at Stephen F. Austin State University (SFA) has both an M.A. and Ph.D. program. SFA is a regional university that is located in Nacogdoches, TX, near the border of Louisiana (i.e., East Texas, TX). Nacogdoches is in a rural area with approximately 33,000 residents (Suburban Stats 2020). The city is 132 miles from Houston, TX, and 165 miles from Dallas, TX. SFA has an overall student population of approximately 13,000.

The School Psychology Program at SFA is unique and needed due to the rural location. There are a total of 10 School Psychology programs in the state of Texas and the nearest to the SFA campus is approximately 76 miles away (Grad Schools 2020). The location also has a shortage of clinical and school mental health professionals; however, many of the students admitted to the program express interest in either serving in the local community or neighboring rural communities. This allows the program to create opportunities for the community to expand the reach of mental health professionals, specifically qualified to work in school systems.

The M.A. in School Psychology Program was authorized by the Texas Higher Education Coordinating Board (THECB) in 2000. It was first approved by the National Association of School Psychologists (NASP) in 2006. The Master's in School Psychology Program adheres to the state requirements for licensure as a Licensed Specialist in School Psychology (LSSP) and the national training standards for certification as a National Certified School Psychologist (NCSP). The training requires 63 semester hours, which includes an internship.

The mission of the program is to ensure students learn to be ethical, responsible, and competent school psychologists. The program approach and teaching are that of the practitionerscientist/scholar. Success refers to accomplishment of not only immediate goals but also long-range goals such as maximizing personal potentials, social integration, meaningful work, and contributing to society (Stoltenberg et al. 2000). Faculty have various backgrounds and credentials including those holding the LSSP, NCSP, BCBA, and/or licensure as psychologists. Faculty are dedicated to ensuring candidates develop high levels of interpersonal and collaborative skills 
and apply cultural competence and sensitivity to diversity as they fulfill their professional, legal, ethical, and social roles in education and society. Students also have access to, and some training in, clinics and centers associated with the School Psychology program including the Human Neuroscience Laboratory, the Janice A. Pattillo Early Childhood Research Center, and the School Psychology Assessment Center.

Due to the program location and need for more school psychologists in the local community and neighboring rural communities, the SFA School Psychology Program created a DE option in 2018 that is delivered via Zoom. It was designed for students at least 50 miles away from the SFA Nacogdoches campus. Applicants must meet the same admission criteria as face-to-face students in the M.A. program and have the ability to attend courses via Zoom video conferencing (i.e., strong Internet connection, webcam, microphone). Students attend classes via synchronous DE. Classes are physically conducted on the SFA campus with face-to-face students and DE students attending virtually through Zoom. In our experience, having DE courses within the traditional classroom with face-to-face students attending allows live discussion to occur as it traditionally would.

\section{Admission Requirements}

In addition to the standard program admission requirements, applicants must meet the criteria to be eligible for admission. The first requirement is that applicants' permanent address must be a minimum of 50 miles distance from the university campus. Additionally, applicants agree that if accepted, they will be able to meet the following criteria:

- Students must attend courses in real-time, with face-toface virtual conferencing via Zoom.

- Some courses and meetings may be required on campus. Students will be notified at the start of each semester dates they will be required to be on the university campus.

- Some courses require assessment materials. For these courses, students must be able and willing to work with an Education Region Service Center in Texas (Texas Education Agency n.d.) or local schools for access to testing kits or travel to campus to check out and return the materials from the program.

- Students will be responsible for all course assignments and program requirements, including thesis, practica, and internship.

- In the event of a technology issue of the instructor's/ university's fault, the instructor will work with the student to ensure appropriate instruction is provided. If a technology issue of the student's fault occurs, the course policy for class absences will be followed according to the syllabus.
Students are admitted to cohorts that include campus-based and distance learning students.

\section{On-site Requirements}

During the course of the program, DE students are required to attend select activities on campus. These requirements are intended to familiarize DE students with program faculty, on-campus peers, and to provide face-to-face in-person experiences for activities that are difficult to complete remotely, consistent with established DE programs in school psychology at other institutions. While the activities reported below have been required by the SFA school psychology program in the past, the program is moving or considering moving many of these activities to DE during the Fall 2020 semester due to the COVID-19 pandemic. It is unclear what the effects of this change may be.

The first of these requirements is the annual student orientation, held prior to the beginning of each Fall semester. Requiring on-campus attendance at orientation helps connect $\mathrm{DE}$ and campus-based students in the program to each other and to program faculty. This assists DE students in establishing relationships with faculty and peers so that they feel connected to the program (Waldron-Soler et al. 2019).

An additional on-campus requirement is in the Fall semester for first-year full-time students. The program holds an annual research event, where students in all research methods courses in the school psychology program present a poster. In addition to student posters, there is an invited paper presentation by university faculty or another professional in a relevant field. This event is highly publicized and well attended by students, faculty, and administrators within the university. Requiring all students to present on campus provides an additional opportunity for faculty and peer connections, as well as professional development and networking experiences.

While both of these events could be attended via DE, program faculty decided to require some on-campus presence by DE students to help support them in building relationships with students and faculty in the program. Faculty believe this is important for students to gain a professional identity and establish a professional network. Student feedback has been overwhelmingly positive in regard to these on-campus requirements.

Students are also required to attend campus for three days to practice and demonstrate skills related to assessment. These designated days are noted in the assessment course syllabus and students are informed when they will be required to attend campus prior to the semester starting.

\section{Use of Technology}

The university has purchased Zoom accounts for all faculty and students. Additionally, school psychology program 
faculty, as well as students enrolled in clinical experience courses each semester, have accounts that are upgraded to be Health Insurance Portability and Accountability Act (HIPAA; Pub. L. No. 104-191) and Family Educational Rights and Privacy Act (20 U.S.C. $§ 1232 \mathrm{~g}$ ) compliant. This allows additional encryption so that meetings are secure. Additionally, several classrooms in the building that house the school psychology program are deemed "refreshed classrooms," as they have been updated with the technology needed to provide DE instruction. The refreshed classrooms on campus have updated Zoom technology, desktop computers (including mouse and keyboard), web cameras that have the ability to move and swivel, projection technology (overhead), external audio speakers, and microphones (at the instructor's presentation desk). In most campus buildings these classrooms offer the basic settings including lights, desks (some may be re-arranged), and a prominent desk at the head of the classroom for the course instructor. However, the campus also has some classrooms that are deemed "Zoom classrooms" or "distance learning classrooms" that were created to help facilitate a seamless Zoom experience. These classrooms have many of the same setup options as the refreshed classrooms; however, they also have a larger space at the head of the classroom designated for instructors, televisions that project lessons and course presentations, more sound-proofing to avoid distractions and less seating than other classrooms due to the expectation that teaching and learning will mostly occur by way of the online platform. The university has invested in distance learning technology and has made available training and troubleshooting resources for faculty and students. Zoom technology is used for all class meetings with DE students, as well as for additional virtual meetings between students and faculty (e.g., advising). During the COVID-19 crisis, the university addressed concerns that many students and employees have limited access to the Internet. Wireless coverage was added in various outdoor areas of campus and extended in range to support safe options to utilizing the Internet while continuing to attend distance courses. Furthermore, the university continues to provide students with guidance on emergency grant funding, including the Coronavirus Aid, Relief, and Economic Security (CARES) Act: Higher Education Emergency Relief Fund (2020), which has awarded grants to 7661 students, to support them in gaining resources they need to continue their education. This includes computers and other materials that may assist in creating a more successful student experience with distance learning. There has also been an effort to ensure students have discounts for these resources through the university.

All program courses are offered as both DE and campusbased. A separate section is opened for each type of student, and then the sections are co-listed, so that campus-based and DE students attend courses together as a cohort. All students are expected to attend classes in real-time and to participate in class discussions. Course requirements are identical for all students, with the exception of the method of class attendance. Additionally, students and faculty utilize Zoom for other meetings, including group project work, virtual office hours, and more.

\section{Navigating Field-Based Work}

One possible area of difficulty in designing and offering a DE program is in courses that include use of assessment materials and those where the primary purpose is field-based work, such as practicum and internship. Our program has addressed this with two options for students: using community resources or using on-campus resources.

There is incredible community support from the Texas Education Region Service Centers for DE students admitted to our program. The program faculty have established relationships with many educational administrators that lead to our DE students' ability to use resources of Education Region Service Centers in their area. These resources can be used in assessment courses so that students are able to access assessment materials to use in learning and practice and for assessment course requirements. For DE students living in areas where the program does not have an ongoing relationship, the student has two options: work with program faculty to establish a relationship between the program and the Education Region Service Center and/or travel to campus to check out and return materials required for use in the courses. To date, all distance learning students have been able to work with their local Education Region Service Centers to use materials.

Practicum and internship requirements for campus-based and DE students are identical. While most campus-based students complete practicum requirements at a site near the university, it is more common for students completing internship to obtain an internship at a site farther from campus. Therefore, the program had already established DE guidelines for the internship. These were then generalized to practicum courses for DE students and include the following:

- Students attend all practicum/internship class meetings in real-time via Zoom

- Students obtain at least the minimum face-to-face supervision required by NASP and the Texas State Board of Examiners of Psychologists from the field supervisor

- Students complete all required hours and activities/assignments, as required by the program

- University supervisors utilize HIPAA and FERPAcompliant Zoom, as well as university email, to communicate with the student and the field supervisor and to complete site visits and field supervisor interviews 
To date, we have had one DE student complete practicum (this student was the first student admitted to the program, we have yet to experience attrition with DE students). Feedback from the student and field supervisors have indicated it was a positive experience and that the student was well prepared for the experience and to continue on to internship. This student was the only person admitted through the DE option in the 2018-2019 academic year, the 2019-2020 cohort included three students, and the 2020-2021 cohort currently includes nine students. As so few students have matriculated through the program at this time, we feel uncomfortable sharing specific outcome data, as it could readily be identified. However, our experience has been that DE students receive grades, comprehensive exam scores, and practicum evaluations that lead to the successful completion of requirements toward the degree.

\section{Partnership with Education Region Service Centers}

Given the widespread shortage of LSSPs in Texas (Barbre 2019), we receive numerous emails and calls asking for current students and alumni to fill positions in the public schools each week. The Region 8 Education Service Center (Texas Education Agency n.d.) reached out to SFA four years ago offering to provide equipment, proctors, and rooms for us to provide DE through their facility for School Psychology training. They expressed concern over being understaffed, having many of their LSSP's close to retirement, and being unable to bring new psychologists into their area. They report much of the problem to be the rural nature of their districts, with schools being many miles apart and having no colleges close enough for people interested in the field to attend. The Region 8 Service Center is more than two hours away from SFA and even further away from other LSSP training programs. They stated they felt they needed to "grow our own," noting that often the only way to get applicants who want to be in their service center area is for the applicant to be from the area, wanting to come home, or wanting to stay close to their childhood homes. The Region 8 Education Service Center in conjunction with SFA School Psychology faculty and interns provided meetings in their facility and numerous flyers, brochures, and phone calls were used to invite people to attend. We had several attendees but no follow through with applicants.

As a faculty, we explored options and decided that designing a program through Zoom for the M.A. degree might be an avenue to address the practitioner shortage as well as the declining number of applicants to our existing program. This was advertised through the 20 Region Education Service Centers in Texas. After this, we were approached by Region 15 Education Service Center about participating in a new project from the Texas Education Agency, because of our online option (Zoom) to get more evaluators in Texas Public schools.
They wrote a Small and Rural Schools grant funded by the Texas Education Agency (https://tea4avoswald.tea.state.tx.us/ GrantOpportunities/forms/GrantProgramSearch.aspx). The region center expressed a desire to work together to provide partial and potentially full funding for individuals who work in a small or rural district and are willing to commit to staying in the district for at least three years. They presented their grant information along with their partners in a training at a regional education conference.

\section{Common DE Issues and Solutions}

DE courses, whether online or hybrid/blended, can cause faculty numerous issues. Online teaching is like learning a new sport; a new sport can be time-consuming and onerous. We strongly encourage faculty considering teaching a DE course to work with the Center of Teaching and Learning, or similar office, on their campus. The Center for Teaching and Learning at SFA requires instructors to complete a semester-long Online Instructor certification program before teaching any online course. We took this class in preparation for working with face-to-face virtual students and frequently collaborate with each other to troubleshoot issues or share new tips and techniques we have learned. Faculty also regularly attend the Center for Teaching and Learning workshops on new instructional strategies that use technological services of benefit to face-to-face in-person and face-to-face virtual students. Instructors should invest a significant amount of time becoming comfortable with virtual learning modalities and interfacing with other individuals on these platforms before engaging in virtual teaching. While such courses are vital, some situations are difficult to anticipate and are learned through lived experiences. We wish to present the common issues we have experienced in this process and possible solutions to these issues (see Table 1).

\section{Passive Students During Lectures}

One of the main complaints of many faculty teaching an online course is passive students (Lieberman 2019). It is difficult to deliver lecture material to the quiet static of muted students without video, not to mention engage in discussion. Face-toface in-person instruction allows faculty to read the faces of their students. The quiet space of the online classroom can be daunting. Zoom offers a solution to this issue.

Zoom (2020) allows real-time polling during instruction. Other learning management systems offer similar options. Faculty can poll students on material as a simple check for understanding or as an opinion poll to increase participation and discussion. The polling can be set to anonymous, which allows students a safe space to voice opinions. This type of active student responding during instruction has a positive 
Table 1 Potential issues and recommendations for the distance education classroom

\begin{tabular}{ll}
\hline Potential issues & Recommendations \\
\hline Passive students during lectures & $\begin{array}{c}\text { Active student responding through polling and checks for } \\
\text { understanding }\end{array}$ \\
$\begin{array}{c}\text { Passive students during self-directed } \\
\text { learning }\end{array}$ & - Model desired behavior \\
Increased emails & - Provide choices within the content \\
& - Provide answers to emails in announcements \\
Creating collaboration & - Create a discussion board for asking questions \\
& - Use breakout groups or create small groups within the online \\
Technical difficulties & environment \\
& - Hold a tech dress rehearsal prior to the start of class to mitigate \\
& issues \\
& - Communicate how technical problems will be handled \\
& - Create documentation of how technical problems will be handled \\
\hline
\end{tabular}

relationship with achievement (Ellis et al. 1994; Greenwood et al. 1984; Rosenshine 2012).

Another strategy is requesting a check for understanding during lectures. Ask students to verbally state or use the chat box "thumbs up" or "thumbs down" to indicate they either understand the material or need more review of the material. The instructor can provide them the option of private messaging if they do not wish to publicly state they do not understand. This technique can promote engagement during online lectures (Rosenshine 2012).

Zoom (2020) also allows the instructor to use a whiteboard. Here, the instructor can draw or write in real time to the student. The instructor can also give control of the whiteboard to a student to answer a problem or demonstrate a skill.

Besides Zoom, there is other software to help increase engagement in the online classroom. Kahoots (2020) and Quizizz (2020) allow the instructor to make a game out of quiz questions, allowing students to compete against each other. These platforms have the added benefit of allowing students to replay the quizzes at a later time to help prepare for exams. Flipgrid (2020) allows the instructor to ask a question and students answer with a video message, creating a social media feel within the classroom.

In a course with both face-to-face in-person and face-toface virtual learners, you can utilize these practices for both groups. You can embed polling into your PowerPoints for traditional learners and use Zoom (2020) polling for distance learners, and you can have the traditional learners physically give a thumbs up or thumbs down during lecture while the face-to-face virtual learners use the chatbox.

\section{Passive Students During Self-Directed Learning}

Struggling to get students to engage in discussion boards and projects in an online classroom is common. Many students take very little action until the end of the semester (Lieberman 2019). This can be time-consuming and frustrating for the instructor.

The instructor can model the behavior they wish to see from the student. For discussion boards and projects, the instructor can provide an example of an exceptional student from a previous semester or complete the project themselves to show exactly what is expected. This will also help alleviate some of the questions about the task.

Another recommendation is to provide choice during these discussion boards and projects. This way the students can engage in self-directed learning and develop interests within the course content. Abrami et al. (2011) found in DE classrooms that providing students with personally meaningful work, which students had some sort of choice in created greater levels of intrinsic motivation. Allowing students to personalize their learning experience will create a better distance experience.

\section{Increased Email Correspondence}

Another potential concern with online classrooms is an increase in email communication with questions from students. One recommendation from Garrison and Vaughan (2007) is to view these emails as part of the instruction. If an instructor receives a question in an email such as "Do I need the latest edition of the book?", they should assume many students are wondering this and post the answer as an announcement. Another recommendation is to create a discussion thread with the title Questions for the instructor. This way every student will be able to benefit from the instructor's answers to the questions, and it may reduce the number of emails asking similar questions. However, it is also important to clearly communicate to students that digital correspondence, particularly in the absence of face-to-face in-person interaction, is important and valued. 


\section{Creating Collaboration in the Online Classroom}

It is difficult sometimes in face-to-face in-person classrooms to create collaboration, and it becomes even more difficult in the face-to-face virtual classroom. Zoom (2020) has breakout rooms. The instructor can choose to place students into smaller groups. During these breakout sessions, the instructor can join different breakout groups to check-in and engage the subgroup in the discussion or activity. When time is up, the instructor is able to give the students a warning timer for when the breakout rooms will end and everyone will return to the larger classroom. This creates a similar environment to the face-to-face in-person classroom, allowing students to work together in small groups. At SFA, when students in the faceto-face in-person classroom were broken up for group work the instructor was able to place the face-to-face virtual students into a breakout room so they could have equivalent experience. Depending on the number of face-to-face inperson and face-to-face virtual students present, creating groups the aforementioned way may be problematic and the instructor may desire to arrange people in groups based on other factors. In this case, face-to-face in-person students can use their phone or laptop to join the virtual breakout rooms.

\section{Technical Difficulties}

The virtual learning environment inevitably comes with technical difficulties. Anything can happen from video not working to full Wi-Fi failure. A few tips to help with this is to hold a tech session prior to the start of class. The instructor and students can work out difficulties prior to the semester beginning. This also can alleviate the anxiety for less tech-savvy students. Providing documents for students to troubleshoot technical issues is also helpful. Often a university's technology office has already created one that can simply be linked to the course.

Online teaching requires much flexibility. During the first class meeting the instructor should discuss with the student how technical difficulties will be handled (i.e., what will happen if the instructor loses the Internet during the allotted course time or what will happen if a student loses the Internet and cannot attend). There also should be a document in the course content with an explanation of these possibilities (e.g., handbook, syllabus, learning management system). With a little planning and a few extra steps, instructors can make the online classroom engaging and easy to navigate for any student.

\section{Conclusion}

Despite being ranked as the 36th best job (U.S. News and World Report n.d.), the field of school psychology continues to face a national shortage (Castillo et al. 2014; Fagan 2004).
One way to address the shortage is for school psychology programs to consider providing instruction via DE (Dixon 2017; Dixon 2018; Moy et al. 2017). To address the national, state, and local shortage of school psychology practitioners and trainers the faculty at SFA began offering a DE option to students outside a 50-mile radius from campus. Although we started with only one student it has expanded with the assistance of Regional Service Centers and district leaders interested in a "grow your own" model. Although the SFA DE option is too young to provide outcome data, there is evidence from existing DE programs that students are adequately trained and prepared for the workforce (Dixon et al. 2020; Drefs et al. 2015; Hendricker and Viola 2019; Ruby et al. 2017; Schroeder 2019; Waldron-Soler et al. 2019). This is in contrast to the majority perception held by school psychology faculty and graduate students that DE training options are inadequate. Program faculty at SFA were also skeptical of DE courses, especially skills-based courses. However, anecdotally, we have not found the DE students' knowledge or skills to be inferior to face-to-face students in our program. Course grades and other outcomes, such as comprehensive exams, are also commensurate between DE and campus-based students, although the sample size is small.

While DE has the potential to increase the recruitment reach of school psychology training programs, provides flexibility to students, and has evidenced similar outcomes between students in DE and non-DE courses (Hendricker et al. 2017), there are some limitations to consider. One limitation is the perspectives of students and applicants. Some graduate students report a lack of interaction and reduced skill acquisition when completing DE courses (Viola et al. 2019). The decreased face-to-face in-person interaction also has the potential to impair the quality of mentorship that can be provided. In particular, it may be more difficult for the faculty member to write strong letters of recommendation when they have limited face-to-face in-person interaction with the person in order to judge their professionalism and ability to interact with others in a live setting. Another potential limitation is faculty perspectives. Luongo (2018) completed a survey with fulltime and part-time faculty teaching DE courses at a university. Results indicate that about $47 \%$ of respondents disagreed that they were as satisfied with teaching DE courses as using other modalities and that about $63 \%$ of participants indicated their workload is higher with DE courses than courses using other modalities. Over $70 \%$ of respondents indicated they either disagreed or strongly disagreed that they missed face-to-face contact with students when teaching DE courses. In addition, Luongo (2018) discusses several factors related to faculty investment and performance in DE, including a lack of administrative support, lack of compensation, and inaccessibility of training and resources.

Accessibility to resources is not limited to a faculty barrier. A number of resources are needed to make DE viable as a 
course modality option. These resources include, but are not limited to, technology and training for faculty and students. Access to equipment and technology can somewhat be overcome by the university providing equipment and hot spots to faculty and students; however, there can continue to be issues with equity of content delivery, particularly for those students living in areas with limited broadband speed capabilities who are not able to travel to provided hot spot locations. Sisneros and Sponsler (2016) report 53\% of individuals living in rural areas have inadequate bandwidth speed, compared with $8 \%$ of individuals living in urban areas. Additionally, they report that as household income decreases, so does the likelihood of individuals having a bandwidth subscription, with lower-income black and Hispanic households being even less likely to purchase bandwidth subscriptions than white low-income households. These data indicate limitations of access and equity across region, income, and race and ethnicity that need to be considered when planning for a DE instructional model.

Access to training and support for faculty and students also need to be considered. A survey by Viola et al. (2020) indicated students in graduate school psychology courses report using a number of technologies in DE courses, including learning management systems (Blackboard, Canvas, etc.), real-time video applications (Skype, Zoom, etc.), and shared drives. Many of these technologies may not have been used by faculty or students prior to the DE course experience, requiring adequate training for best use of technology by faculty and usability for students. Universities can provide this training through professional development opportunities and support services.

Students in a "grow your own" environment often have restricted supervisor options, which is another limitation DE programs may face when trying to identify and select qualified supervisors for DE students. Providing training to supervisors and developing strong bilateral communication with supervisors about course requirements and evaluation of student performance is also a challenge from a geospatial distance.

While additional limitations will no doubt be experienced by programs transitioning to a DE model, faculty and student perspectives, technology access and equity, and training and support appear to be most frequently cited in the current literature. While these limitations may result in barriers to effective DE course delivery, many can be overcome with careful planning and resource allocation. Programs considering DE should work with university administration to prepare for and prevent these barriers to the extent possible prior to offering DE courses.

School psychology DE courses and DE programs have received increased attention in professional outlets (i.e., the Communique, journal articles, special issues) recently. Although we anticipated this trend to continue before the pandemic, we more firmly believe DE options will become more prevalent as faculty and student have been provided opportunities to experience and become more comfortable with this format. Nonetheless, much more research is warranted and the discussion of how best to prepare students in skill-based classes is needed.

Data Availability Not applicable.

\section{Compliance with Ethical Standards}

Conflict of Interest The authors are affiliated with the program featured in this paper.

Ethical Approval Not applicable.

Consent to Participate Not applicable.

Consent for Publication Not applicable.

Code Availability Not applicable.

\section{References}

Abrami, P. C., Bernard, R. M., Bures, E. M., Borokhovski, E., \& Tamim, R. M. (2011). Interaction in distance education and online learning: using evidence and theory to improve practice. Journal of Computing in Higher Education, 23(2-3), 82-103. https://doi.org/ 10.1007/s12528-011-9043-x.

Barbre, S. (2019). A report on the state of school psychology in Texas schools: 2017-2018 school year. Research and Practice in the Schools, 6(1), 1-10.

Brock, S. E. (2015). Where are the school psychologists? Communique, 43(8), 2.

Castillo, J. M., Curtis, M. J., \& Tan, S. Y. (2014). Personnel needs in school psychology: a 10-year follow-up study on predicted personnel shortages. Psychology in the Schools, 51(8), 832-849. https:// doi.org/10.1002/pits.21786.

Coronavirus Aid, Relief, And Economic Security Act: higher education emergency relief fund. U.S.C. § 116. (2020). https://www2.ed.gov/ about/offices/list/ope/caresact.html.

Dixon, R. J. (2017). Online education: let's start the conversation. Communique, 46(2), 26-27.

Dixon, R. J. (2018, March/April). Online school psychology: blueprint to higher education conversation. Communique, 46(6), 16-18.

Dixon, R. J., Kitson, J., Somer, C., Mangus, L., Chaffin, J., \& Hendricker, E. (2020). Extending the university walls: using technology to prepare future practitioners. Communique, 48(7), 10-12.

Drefs, M. A., Schroeder, M., Hiebert, B., Panayotidis, E. L., Winters, K., \& Kerr, J. (2015). Canadian innovation: a brief history of Canada's first online school psychology graduate program. Canadian Journal of School Psychology, 30, 288-303.

Ellis, E. S., Worthington, L. A., \& Larkin, M. J. (1994). Effective teaching principle and the design of quality tools for educators. Unpublished Paper Commissioned by the Center for Advancing the Quality of Technology, Media, and Material, University of Oregon. 3-108.

Fagan, T. (2004). School psychology's significant discrepancy: historical perspectives on personnel shortages. Psychology in the Schools, 41(4), 419-430. https://doi.org/10.1002/pits.10185. 
Fischer, A. J., Moy, G. E., \& Robbins, S. E. (2018). Online content instruction in school psychology training. Communique, 47(1), 20-21.

Fischer, A. J., Moy, G. E., Bloomfield, B. S., Whitcomb, S., \& Florell, D. (2020). Faculty perceptions of distance education in school psychology training. Trainers' Forum: Journal of the Trainers of School Psychologists, 37(1), 34-43.

Flipgrid. (2020). Flipgrid. (Version 4.2) [Computer software]. Retrieved September 18, 2020, from https://www.flipgrid.com

Fort Hayes State University. (n.d.). Online school psychology program. Retrieved May 20, 2020, from https://www.fhsu.edu/psych/online\% 20school\%20psych/online-school-psychology

Garrison, D. R., \& Vaughan, N. D. (2007). Blended learning in higher education: framework, principles, and guidelines. Madison, WI: Jossey-Bass.

Grad Schools. (2020). School psychology programs and degrees in Texas. Retrieved 13 May 2020, from https://www.gradschools. com/programs/educational-school-psychology/school-psychology? in=texas.

Greenwood, C. R., Delquadri, J., \& Hall, R. V. (1984). Opportunity to respond and student academic performance. In W. K. Heward, T. E. Heron, J. Trap-Porter, \& D. S. Hill (Eds.), Focus on behavior education (pp. 58-88). Charles Merrill.

Hendricker, E., \& Viola, S. (2019, October). Using distance education with nontraditional school psychology students. Communique, $48(2), 4$.

Hendricker, E., Saeki, E., \& Viola, S. (2017). Trends and perceptions of distance learning in school psychology. Trainer's Forum, 37(2), 3769.

Kahoots. (2020). Kahoot. (Version 6.0.1) [Computer software]. Retrieved May 13, 2020, from https://www.kahoot.com.

Lieberman, M. (2019). Discussion boards: Valuable? Oversued? Discuss. Inside Higher Ed. https://www.insidehighered.com/digitallearning/ article/2019/03/27/new-approaches-discussion-boards-aimdynamic-online-learning.

Luongo, N. (2018). An examination of distance learning faculty satisfaction levels and self-perceived barriers. Journal of Educators Online, 15(2) https://files.eric.ed.gov/fulltext/EJ1186012.pdf.

Moy, G., Chaffin, J., \& Fischer, A. (2017). Opportunities and challenges for online instruction in school psychology programs. Communique, 46(3), 17-18.

Moy, G., Robbins, S., \& Fischer, A. J. (2018). Key concepts and terminology in online instruction: a primer for school psychology programs. Communique, 46(5), 4-6.

Quizizz. (2020). Quizizz. (Version 4.27). [Computer software]. Retrieved May 13, 2020, from https://www.quizizz.com.

Reeves, M. (2016). Inspiration in small steps. Communique, 45(3), 2.

Rosenshine, B. (2012). Principles of instruction: research-based strategies that all teachers should know. American Educator, 36(1), 12-19.

Ruby, S. F., Chaffin, J. M., \& Islam-Zwart, K. (2017). Quality distance learning to address the school psychology shortage: A model for online respecialization. Trainer's Forum, 34(3), 43-61.

Savage, T. (2016). School psychology matters. Communique, 44(7), 2.

Schroeder, M. (2019). Preparation for a premaster's internship in a blended school psychology program: a case study. Training and Education in Professional Psychology. Advance online publication. https://doi.org/10.1037/tep0000296

Sisneros, L. \& Sponsler, B. A. (2016). Broadband access and implications for efforts to address equity gaps in postsecondary attainment.
Retrieved August 7, 2020 from https://files.eric.ed.gov/fulltext/ ED565437.pdf.

Stoltenberg, C. D., Pace, T. M., Kashubeck-West, S., Biever, J. L., Patterson, T., \& Welch, I. D. (2000). Training models in counseling psychology: scientist-practitioner versus practitioner-scholar. The Counseling Psychologist, 28(5), 622-640.

Suburban Stats. (2020). Current Nacogdoches, Texas population, demographics and stats in 2019, 2020. Retrieved 13 May 2020, from https://suburbanstats.org/population/texas/how-many-people-livein-nacogdoches.

Texas Education Agency. (n.d.). Education service centers. Retrieved May 21, 2020, from https://tea.texas.gov/about-tea/other-services/ education-service-centers.

U.S. News \& World Report. (n.d.). School psychologist overview. Retrieved May 21, 2020, from https://money.usnews.com/careers/ best-jobs/school-psychologist.

Viola, S., Saeki, E., \& Hendricker, E. (2019). Distance education in graduate training programs: lessons learned from school psychology students. Journal of Educators Online, 16(2), 1-17.

Viola, S., Hendricker, E., \& Saeki, E. (2020). Instructional technology in graduate psychology distance education: trends and student preferences. Journal of Educators Online, 17(1) https://eric.ed.gov/?id= EJ1241547.

Waldron-Soler, K. M., Ruby, S. F., \& Chaffin, J. M. (2019). Learning from graduate training in related fields: a model online school psychology program. Rural Special Education Quarterly, 38, 107-118. https://doi.org/10.1177/8756870519826933.

Wayne State University (n.d.). Master of art in school and community psychology. Retrieved May 20, 2020, from https://coe.wayne.edu/ tbf/educational-psychology/ma_in_school_and_community_ psychology_online.php.

Zoom. (2020). Zoom. (Version 5.0.1) [Computer Software]. Retrieved May 20, 2020, from https://zoom.us/.

Publisher's Note Springer Nature remains neutral with regard to jurisdictional claims in published maps and institutional affiliations.

Dr. Daniel F. McCleary is an associate professor at Stephen F. Austin State University. His primary interests include math fluency and the scholarship of teaching and learning.

Dr. Frankie J. Clark is a clinical professor at Stephen F. Austin State University. She has 40 plus years in private practice in Deep East Texas. Currently she is the Director of the APA accredited SFA Charter School Psychology Internship Program.

Dr. Jillian Dawes is now an assistant professor at The Citadel. Her interests include math fluency and behavior analysis.

Dr. Jaime M. Flowers is an assistant professor at Stephen F. Austin State University. Her interests include bullying and behavior analysis.

Dr. Nina Ellis-Hervey is an associate professor at Stephen F. Austin State University. Her interests include selfesteem, locus of control, and personal presentation difficulties encountered by women of color. 